\title{
Modified Kithul (Caryota urens) Flour as a Plant Origin Stabilizing Agent in Drinking Yoghurt
}

\author{
J. A. A. C. Wijesinghe ${ }^{1 *}$, I. Wickramasinghe ${ }^{2}$ and K. H. Sarananda ${ }^{1}$
}

\begin{abstract}
The objective of this study was to use Kithul (Caryota urens) flour as a plant origin stabilizer for production of drinking yoghurt. The investigation was planned to choose most suitable modified type of Kithul flour (Raw Kithul flour and two types of pre-gelatinized Kithul flour as PGI and PGII), and the best process to make appropriate hydration and suitable flour concentration $(0.5 \%$ and $1 \%)$. Six formulations, which gave the most agreeable condition on textural and sensory characteristics of final drinking yoghurt products were tested. Physicochemical and sensory attributes for different periods of time ( 0,2 and 8 days) were also analyzed. The pre-gelatinized ( $75{ }^{\circ} \mathrm{C}$ for 5 minutes) modified Kithul flour namely PG II was the best type of Kithul flour among all treatments, while Process II, which gave $24 \mathrm{~h}$ refrigeration condition to combine starch granules with milk was selected as the best process to maintain the most preferable texture for drinking yoghurt. The best flour concentration to keep unique texture and market preference of newly formulated drinking yoghurt was $1 \%$.
\end{abstract}

${ }^{1}$ Department of Biosystems Engineering, Faculty of Agriculture and Plantation Management, Wayamba University of Sri Lanka, Gonawila 60170, Sri Lanka.

${ }^{2}$ Department of Food Science and Technology, Faculty of Applied Sciences, University of Sri Jayewardenepura, Nugegoda 10250, Sri Lanka.

*jaacwijesinghe@wyb.ac.lk
Keywords: Caryota urens, Drinking yoghurt, Modified Kithul flour, Physicochemical properties, Sensory attributes

\section{INTRODUCTION}

The name of yoghurt is initiated by Turkish word 'Yogen' that is thick (Shahnawaz et al., 2013). This semi-fermented milk product was invented in Bulgaria and now its demand has grown all over the world with numerous modifications (Lee and Lucey, 2010).

The structure of yoghurt has been described as a combined gel that is organized as a three-dimensional casein network collected through isoelectric precipitation caused by lactic acid bacterial action, which is filled with denatured serum proteins and fat globules (AguirreMandujano et al., 2009). Therefore, the structural arrangement of raw milk (Crion et al., 2012), actions of starter culture and manufacture conditions (Lal et al., 2006) are responsible for palatability and textural stability of yoghurt. Stabilizers increase consumer attraction of yoghurt by undertaking two elementary tasks as the binding of water and enhancement of texture (Kumar and Mishra, 2004). 
Hydrocolloids are widely used as stabilizers to improve the textural properties of yoghurt and to reduce the syneresis. Gelatin is the most popular hydrocolloid used for the production of yoghurt (Collins et al., 1991). However, the negative impact is that the main sources of gelatin include cattle and bovine slaughterhouse by-products such as skins, tails, hides and bones that come under the non-vegetarian category. Vegetarians who want to consume dairy products are deprived of their opportunity due to incorporation of gelatin in yoghurt. Moreover, there is creating demand to find and use alternative substitutes which can improve yoghurt texture as same as gelatin. Not only religious limitations but also based on the outbreak of mad cow disease in the 1980s, there is an increasing concern on possibility of transmitting pathogenic vectors via animal tissue-derived materials including collagen and gelatin (Karim and Bhat, 2009).

Modified Starch is one of the most commonly used plant origin stabilizers in recent yoghurt production due to its ease of processing and low cost when compared to other existing hydrocolloids (Foss, 2000). Starch granules can absorb water and swell to many times than their original size, resulting in increased viscosity of the solution which accomplishes the basic functions of a stabilizer (Okoth et al., 2011). In this context, Kithul (Caryota urens) flour, which is a low-cost and nutritious alternative for gelatin, could be a suitable candidate.
Presently, increased attention is being paid to plant products as uncommon food resources in the wild considering their potentials in new product development (Rajyalakshmi, 2004). Kithul flour has gained significant attention as it is equal in quality to commercially popular sago obtained from Metroxylon sagu (Anon. 1992). Gel forming ability is a key functional property of Kithul flour which can be used in the food industry for production of jellies, jams and similar products which require stabilizers (Wijesinghe et al., 2014).

The objective of this study was, therefore, to identify the most suitable modified type of Kithul flour (among raw Kithul flour and two types of pre-gelatinized Kithul flour) for production of drinking yoghurt. Kithul flour types were also combined with processes (process I and process II) to determine the appropriate hydration and suitable flour concentration $(0.5 \%$ and $1 \%)$, to improve textural and sensory characteristics of the final drinking yoghurt product.

\section{MATERIALS AND METHODS Raw Material for Yoghurt Production}

The fresh milk of acceptable organoleptic and microbial quality was obtained from a selected local supplier. Sucrose and non-fat milk powder were obtained from the local market in Colombo, Sri Lanka. The starter culture was obtained from Christian Hansen, Germany (STI 12) through a reputed agent 
in Colombo, Sri Lanka. The used starter culture was a thermophilus yoghurt starter culture with Streptococcus thermophiles and Lactobacillus bulgaricus microorganisms.

\section{Flour Sample Collection and Modification}

Freshly prepared Kithul flour (RW) samples were used for the modifications and all samples were sifted through a $355 \mu \mathrm{m}$ sieve before further analysis.

\section{Effect of Pre-gelatinization Modifications of Kithul Flour on Quality of Yoghurt (Experiment 1)}

Pre-gelatinized modification (PG) was done with slight modification of the method described by Knight (1969; cited by Karaoglu et al., 2001). A 1:1 flour suspension $(100 \mathrm{~g}$ flour for $100 \mathrm{ml}$ deionized water) was incubated either at $70{ }^{\circ} \mathrm{C}$ (PG-I) or $75{ }^{\circ} \mathrm{C}$ (PG-II) for $5 \mathrm{~min}$. Gelatinized flour was dried in a hot air dryer at $40{ }^{\circ} \mathrm{C}$ till moisture level dropped to $10 \%-15 \%$. Raw Kithul flour was used as the control. Ingredients were mixed according to the formula given in Table 1 and yoghurt was prepared according to process I in Figure 1.

\section{Effect of Processing Method on Quality of Yoghurt (Experiment 2)}

Based on results of Experiment 1, PG-II was used as the preferred flour type, and yoghurt was prepared according to the two procedures given in Figure 1. The ingredients were mixed based on the formula given in Table 1.

\section{Effect of Flour Concentration on Quality of Yoghurt (Experiment 3)}

Pre-gelatinized modification-II (PG-II) was used as the preferred flour type, and yoghurt was prepared according to the formula in Table 1 altering only the flour concentration. Three sets of samples were formulated with $0 \%$ (control), $1 \%$ and $2 \%$ flour concentrations while all other ingredients were kept constant. Control samples were prepared according to process I in Figure 1 whereas treatment samples were prepared according to process II. Yoghurt samples were prepared as depicted in Figure 1.

\section{Process for Production of Yoghurt Culture Preparation}

Daughter culture was made using UHT treated fresh milk. The milk was heated to $45^{\circ} \mathrm{C}$ and inoculated with STI 12 yoghurt culture (50 $\mathrm{U}$ in $400 \mathrm{l}$ of milk) according to the producer's recommendation (Chr. Hansen). Samples were incubated at $43{ }^{\circ} \mathrm{C}$ for $6 \mathrm{~h}$ and $30 \mathrm{~min}$. The fermentation was stopped once the $\mathrm{pH}$ reached 4.6. The set yoghurt samples with compact coagulum were cooled and stored at $4{ }^{\circ} \mathrm{C}$.

Process -I

The modified or raw flour according to the recipes $\mathrm{A}, \mathrm{B}, \mathrm{C}$ and $\mathrm{E}$ in Table 1 and skimmed milk powder were mixed with 
sugar prior to addition of milk (Table 1). The milk was heated to $40{ }^{\circ} \mathrm{C}$ and the mixture was added (Figure 1).

The samples were then pasteurized at 90 ${ }^{\circ} \mathrm{C}$ for $30 \mathrm{~min}$ in a boiling pan. The milk was then cooled to $45{ }^{\circ} \mathrm{C}$ and inoculated with $2 \%$ yoghurt culture (daughter culture). It was stirred for $30 \mathrm{~s}$ for complete dissolution and equal distribution of culture granules in

\section{Process -I (For formulation A, B, C and E)}

All ingredients according to Table 1 (except milk) were mixed (Y) together. milk. The milk was incubated at $45{ }^{\circ} \mathrm{C}$ for 5 $\mathrm{h}$ until a firm curd was formed at the top and a $\mathrm{pH}$ of $4.1-4.4$ was obtained. It was then aged at $5{ }^{\circ} \mathrm{C}$ overnight to allow cooling. The curd was broken by swirling 40 times with a hand stirrer to form a smooth homogeneous product. It was then stored under refrigeration at $4{ }^{\circ} \mathrm{C}$ for further analysis.

\section{Process -II (For formulation D and F)}

Modified Kithul flour (PG II) and fresh milk were mixed well.

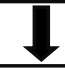

Mixture was aged at $5^{\circ} \mathrm{C}$ overnight

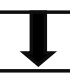

All ingredients according to Table I (except milk and PG II) were mixed (Z) together.

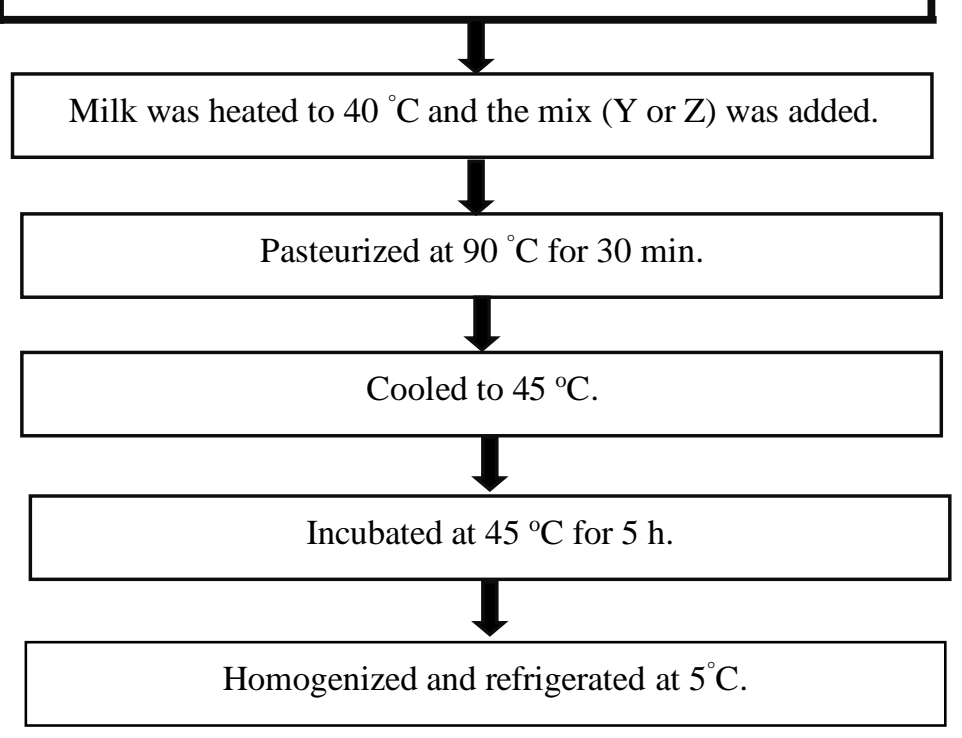

Figure 1. Process flow for production of drinking yoghurt with Kithul (Caryota urens) flour 
Table 1. Formulation of new yoghurt recipes with modified Kithul flour

\begin{tabular}{lllllll}
\hline \multicolumn{1}{c}{ Ingredient } & Sample A & Sample B & Sample C & Sample D & Sample E & Sample F \\
\hline Fresh milk & $200 \mathrm{ml}$ & $200 \mathrm{ml}$ & $200 \mathrm{ml}$ & $200 \mathrm{ml}$ & $200 \mathrm{ml}$ & $200 \mathrm{ml}$ \\
Non-fat milk powder & $2 \mathrm{~g}$ & $2 \mathrm{~g}$ & $2 \mathrm{~g}$ & $2 \mathrm{~g}$ & $2 \mathrm{~g}$ & $2 \mathrm{~g}$ \\
$\begin{array}{l}\text { Type of Kithul flour } \\
\text { Amount of Kithul flour }\end{array}$ & PG-I & PG-II & $\mathrm{RW}$ & PG-II & Not added & PG-II \\
Amount of culture (from daughter & $2 \mathrm{~g}$ & $2 \mathrm{~g}$ & $2 \mathrm{~g}$ & $2 \mathrm{~g}$ & - & $1 \mathrm{~g}$ \\
culture) & $4 \mathrm{~g}$ & $4 \mathrm{~g}$ & $4 \mathrm{~g}$ & $4 \mathrm{~g}$ & $4 \mathrm{~g}$ & $4 \mathrm{~g}$ \\
$\begin{array}{l}\text { Sugar } \\
\text { Applied process }\end{array}$ & $40 \mathrm{~g}$ & $40 \mathrm{~g}$ & $40 \mathrm{~g}$ & $40 \mathrm{~g}$ & $40 \mathrm{~g}$ & $40 \mathrm{~g}$ \\
\hline
\end{tabular}

PG: Pre-gelatinization modification by incubating at $70^{\circ} \mathrm{C}$ (PG-I) or $75^{\circ} \mathrm{C}$ (PG-II) for 5 min. RW: Raw Kithul flour

\section{Process -II}

The modified flour according to the recipe (D and $\mathrm{F}$ in Table 1) and fresh milk were mixed prior to addition of other ingredients as given in Table 1 . The mixture was aged at $5{ }^{\circ} \mathrm{C}$ overnight for cooling. Then, other ingredients were added to the cooled milk and flour mixture. Subsequent steps were followed as described previously under the process- 1 .

\section{Methods of Analysis}

All the tests were conducted thrice, on the $1^{\text {st }}, 2^{\text {nd }}$ and $8^{\text {th }}$ day of storage at $5{ }^{\circ} \mathrm{C}$. Yoghurt samples were analyzed for $\mathrm{pH}$, ${ }^{\circ}$ Brix, moisture content, total solids and sensory properties.

\section{Determination of pH of Yoghurts}

The $\mathrm{pH}$ of yoghurt samples was determined according to the method described by the Adolfo Lutz Institute (Vasconcelos et al.,
2012) through direct reading with a digital pH meter (Hanna pH meter No. 211) using a $10 \mathrm{ml}$ sample.

\section{Determination of Total Soluble Solids Content $\left({ }^{\circ}\right.$ Brix)}

Total soluble solid (TSS) contents of yoghurt samples were measured directly using a bench-top ABBE refractometer (São Paulo, Brazil) at room temperature of $27 \pm 3{ }^{\circ} \mathrm{C}$ and the results were expressed in ${ }^{\circ} \mathrm{Brix}$ (Vasconcelos et al., 2012).

\section{Determination of Moisture Content (\%)}

The moisture content was determined by oven method as described by AOAC (2005). In this process, $2 \mathrm{~g}$ of the sample was dried in a hot air oven for $24 \mathrm{~h}$ at $100{ }^{\circ} \mathrm{C}$. The weight loss was determined as the moisture content and expressed as;

$\%$ moisture $=\underline{\mathrm{W} 1-\mathrm{W} 2 \times 100}$

$\mathrm{W} 1$ 
Where;

$\mathrm{W} 1$ = Initial weight of the sample

$\mathrm{W} 2=$ Weight of the dried sample

\section{Determination of Total Solids (TS \%)}

The Total Solids content was determined as described by AOAC (2005). A sample of $3 \mathrm{~g}$ was weighed into a dry Petri-dish of a known weight. The total portion was predried for $25 \mathrm{~min}$ on a steam bath and dried for $3 \mathrm{~h}$ at $100{ }^{\circ} \mathrm{C}$ in a forced air oven. The total solid content is the weight of the dried sample residue and was calculated as:

$$
\% \text { Total Solid }=\frac{\mathrm{W} 2 \times 100}{\mathrm{~W} 1}
$$

Where;

$$
\begin{aligned}
& \mathrm{W} 1=\text { Weight of the initial (wet) sample } \\
& \mathrm{W} 2=\text { Weight after drying }
\end{aligned}
$$

\section{Sensory Evaluation}

The sensory evaluation of yoghurt was done by 30 untrained/semi-trained panelists using a seven-point scale (7 for 'like extremely' down to 1 for 'dislike extremely') to score each attribute (El Owni and Mahgoub, 2012).

\section{Statistical Analysis}

A completely randomized design with three replications was used to determine the differences between pre-gelatinized modifications of flour samples and concentrations of flour. Results were analyzed using one-way analysis of variance (ANOVA) at 0.05 probability level using MINITAB software package (version 17).

\section{RESULTS AND DISCUSSION pH and Total Soluble Solids Content of Yoghurt}

The negative logarithm of the hydrogen ion concentration is called $\mathrm{pH}$. It is a more realistic measurement of the acidity of a product than titratable acidity because titratable acidity gives a reading of the quantity while $\mathrm{pH}$ gives the measurement of the power of that acid (Bibiana et al., 2014).

The results on $\mathrm{pH}$ of three sets of drinking yoghurt samples, depicted in Table 2 show that $\mathrm{pH}$ of the yoghurt samples was significantly affected by different concentrations of Kithul flour (raw or modified) and by storage durations. The $\mathrm{pH}$ of yoghurt samples decreased as storage time increased, which could be due to a conversion of lactose into lactic acid. According to the Food Standard Code requirement, $\mathrm{pH}$ of yoghurt should be a maximum of 4.5 to prevent growth of pathogens (Donkor et al., 2006). According to previous research, values of $\mathrm{pH}$ higher than 4.6 also resulted in whey separation as the gel was not formed (Vasconcelos et al., 2012).

From the $1^{\text {st }}$ set of samples, B had a 
preferable initial $\mathrm{pH}$ than $\mathrm{A}$ and $\mathrm{C}$ while from the $2^{\text {nd }}$ comparison set it presented more appropriate $\mathrm{pH}$ than $\mathrm{D}$ and $\mathrm{E}$. However, from the $3^{\text {rd }}$ set of sample comparison $\mathrm{E}$ had preferable $\mathrm{pH}$ value for drinking yoghurt at the initial stage. Accordingly, with $\mathrm{pH}$, sample B (4.57) was the best formulation out of five. Sample D, which was prepared with the same formula as B (only the process was different), showed an appropriate $\mathrm{pH}$ value (4.57) after eight days of storage which could be considered a positive character to maintain least post acidification during shelf life (Table 2). It could be due to high absorption of water by modified flour, making water unavailable for starter cultures. Consequently, the activity of starter cultures decreased resulting in low lactic acid production (Tamime and Rabinson, 1999; Tavakolipour et al., 2014).

The total soluble solids (TSS) content of drinking yoghurt samples decreased with storage time except in A and C (Table 2). This observation corresponds to the results of Vasiljevic and Jelen (2002) and Wang et al. (2002) where the TSS content of the medium decreased as a result of use of sugar by the starter culture during fermentation. Highest TSS reduction was reported in sample D and the control. It appeared that sample D behaved similar to control sample (E), and the reason could be the applied process II. Sample D contained TSS in the most appropriate form that can be consumed by microbes.

Table 2. $\mathrm{pH}$ and total soluble solids content $\left({ }^{\circ}\right.$ Brix $)$ of drinking yoghurt formulated with Kithul flour

\begin{tabular}{|c|c|c|c|c|c|c|c|}
\hline \multicolumn{2}{|c|}{ Sample Name } & \multicolumn{3}{|c|}{ pH } & \multicolumn{3}{|c|}{${ }^{\circ}$ Brix } \\
\hline & & Initial & $\begin{array}{c}\text { After } 2 \\
\text { Days }\end{array}$ & $\begin{array}{c}\text { After } 8 \\
\text { Days }\end{array}$ & Initial & $\begin{array}{c}\text { After } 2 \\
\text { Days }\end{array}$ & $\begin{array}{c}\text { After } 8 \\
\text { Days }\end{array}$ \\
\hline \multirow{3}{*}{$1^{\text {st }}$ Set } & $\mathrm{A}$ & $5.10 \pm 0.01^{\mathrm{a}}$ & $5.05 \pm 0.04^{\mathrm{a}}$ & $4.84 \pm 0.01^{\mathrm{a}}$ & $27.67 \pm 0.50^{\mathrm{b}}$ & $28.00 \pm 0.50^{\mathrm{b}}$ & $27.67 \pm 0.50^{b}$ \\
\hline & $\mathrm{B}$ & $4.57 \pm 0.03^{b}$ & $4.43 \pm 0.03^{b}$ & $4.35 \pm 0.01^{\mathrm{c}}$ & $25.33 \pm 0.50^{c}$ & $25.67 \pm 0.50^{c}$ & $24.67 \pm 0.50^{c}$ \\
\hline & $\mathrm{C}$ & $5.08 \pm 0.01^{\mathrm{a}}$ & $5.03 \pm 0.01^{\mathrm{a}}$ & $4.65 \pm 0.01^{\mathrm{b}}$ & $29.00 \pm 0.50^{\mathrm{a}}$ & $29.67 \pm 0.50^{\mathrm{a}}$ & $29.67 \pm 0.50^{\mathrm{a}}$ \\
\hline \multirow{3}{*}{$2^{\text {nd }}$ Set } & $\mathrm{B}$ & $4.57 \pm 0.03^{b}$ & $4.43 \pm 0.03^{b}$ & $4.35 \pm 0.01^{\mathrm{b}}$ & $25.33 \pm 0.50^{\mathrm{b}}$ & $25.67 \pm 0.50^{\mathrm{a}}$ & $24.67 \pm 0.50^{\mathrm{a}}$ \\
\hline & $\mathrm{D}$ & $4.87 \pm 0.04^{\mathrm{a}}$ & $4.75 \pm 0.02^{\mathrm{a}}$ & $4.58 \pm 0.031^{\mathrm{a}}$ & $25.67 \pm 0.50^{\mathrm{b}}$ & $24.33 \pm 0.50^{\mathrm{a}}$ & $22.67 \pm 0.50^{c}$ \\
\hline & $\mathrm{E}$ & $4.45 \pm 0.04^{\mathrm{c}}$ & $4.25 \pm 0.04^{\mathrm{c}}$ & $4.17 \pm 0.02^{\mathrm{c}}$ & $26.67 \pm 0.50^{\mathrm{a}}$ & $25.67 \pm 0.50^{\mathrm{a}}$ & $23.67 \pm 0.50^{\mathrm{b}}$ \\
\hline \multirow{3}{*}{$3^{\text {rd }}$ Set } & $\mathrm{D}$ & $4.87 \pm 0.04^{\mathrm{a}}$ & $4.75 \pm 0.02^{\mathrm{a}}$ & $4.58 \pm 0.031^{\mathrm{a}}$ & $25.67 \pm 0.50^{\mathrm{b}}$ & $24.33 \pm 0.50^{\mathrm{a}}$ & $22.67 \pm 0.50^{\mathrm{b}}$ \\
\hline & $\mathrm{E}$ & $4.45 \pm 0.04^{\mathrm{b}}$ & $4.25 \pm 0.04^{b}$ & $4.17 \pm 0.02^{\mathrm{b}}$ & $26.67 \pm 0.50^{\mathrm{a}}$ & $25.67 \pm 0.50^{\mathrm{a}}$ & $23.67 \pm 0.50^{\mathrm{a}}$ \\
\hline & $\mathrm{F}$ & $4.24 \pm 0.03^{c}$ & $4.00 \pm 0.02^{\mathrm{c}}$ & $4.08 \pm 0.02^{\mathrm{c}}$ & $25.33 \pm 0.50^{\mathrm{b}}$ & $24.33 \pm 0.50^{b}$ & $24.00 \pm 0.00^{\mathrm{a}}$ \\
\hline
\end{tabular}

Values are mean $\pm S D ; n=3$. The values in a column, within a set, followed by same superscript letters are not statistically different at the significance level of $5 \%$. 
Table 3. Moisture content (MC) and total solids (TS) content of drinking yoghurt formulated with Kithul flour

\begin{tabular}{|c|c|c|c|c|c|c|c|}
\hline \multicolumn{2}{|c|}{ Sample Name } & \multicolumn{3}{|c|}{ Moisture Content (\%) } & \multicolumn{3}{|c|}{ Total Solids Content (\%) } \\
\hline & & Initial & $\begin{array}{c}\text { After } 2 \\
\text { Days }\end{array}$ & $\begin{array}{c}\text { After } 8 \\
\text { Days }\end{array}$ & Initial & After 2 Days & After 8 Days \\
\hline \multirow{3}{*}{$1^{\text {st }}$ Set } & A & $63.25 \pm 0.12^{\mathrm{b}}$ & $64.49 \pm 0.33^{b}$ & $65.59 \pm 0.38^{\mathrm{b}}$ & $36.01 \pm 0.10^{\mathrm{b}}$ & $35.70 \pm 0.14^{\mathrm{b}}$ & $34.67 \pm 0.25^{\mathrm{b}}$ \\
\hline & B & $64.32 \pm 0.21^{\mathrm{a}}$ & $65.56 \pm 0.49^{\mathrm{a}}$ & $66.60 \pm 0.34^{\mathrm{a}}$ & $35.70 \pm 0.14^{\mathrm{b}}$ & $34.46 \pm 0.27^{\mathrm{c}}$ & $33.41 \pm 0.32^{\mathrm{c}}$ \\
\hline & $\mathrm{C}$ & $61.17 \pm 0.20^{\mathrm{c}}$ & $62.61 \pm 0.44^{\mathrm{c}}$ & $57.53 \pm 0.28^{c}$ & $41.03 \pm 1.29^{\mathrm{a}}$ & $37.82 \pm 0.28^{\mathrm{a}}$ & $35.93 \pm 0.07^{\mathrm{a}}$ \\
\hline \multirow{3}{*}{$2^{\text {nd }}$ Set } & $\mathrm{B}$ & $64.32 \pm 0.21^{\mathrm{b}}$ & $65.56 \pm 0.49^{b}$ & $66.60 \pm 0.34^{\mathrm{b}}$ & $35.70 \pm 0.14^{\mathrm{b}}$ & $34.46 \pm 0.27^{\mathrm{b}}$ & $33.41 \pm 0.32^{\mathrm{c}}$ \\
\hline & $\mathrm{D}$ & $60.44 \pm 0.24^{\mathrm{c}}$ & $56.30 \pm 0.15^{\mathrm{c}}$ & $48.37 \pm 0.25^{\mathrm{c}}$ & $45.23 \pm 0.26^{\mathrm{a}}$ & $43.51 \pm 0.30^{\mathrm{a}}$ & $50.90 \pm 0.71^{\mathrm{a}}$ \\
\hline & $\mathrm{E}$ & $65.48 \pm 0.22^{\mathrm{a}}$ & $67.62 \pm 0.33^{\mathrm{a}}$ & $69.55 \pm 0.42^{\mathrm{a}}$ & $33.24 \pm 0.17^{\mathrm{c}}$ & $32.65 \pm 0.15^{\mathrm{c}}$ & $34.44 \pm 0.26^{\mathrm{b}}$ \\
\hline \multirow{3}{*}{$3^{\text {rd }}$ Set } & $\mathrm{D}$ & $60.44 \pm 0.24^{\mathrm{c}}$ & $56.30 \pm 0.15^{\mathrm{c}}$ & $48.37 \pm 0.25^{\mathrm{c}}$ & $45.23 \pm 0.26^{\mathrm{a}}$ & $43.51 \pm 0.30^{\mathrm{a}}$ & $50.90 \pm 0.71^{\mathrm{a}}$ \\
\hline & $\mathrm{E}$ & $65.48 \pm 0.22^{\mathrm{a}}$ & $67.62 \pm 0.33^{\mathrm{a}}$ & $69.55 \pm 0.42^{\mathrm{a}}$ & $33.24 \pm 0.17^{\mathrm{c}}$ & $32.65 \pm 0.15^{\mathrm{c}}$ & $34.44 \pm 0.26^{\mathrm{b}}$ \\
\hline & $\mathrm{F}$ & $64.32 \pm 0.21^{\mathrm{b}}$ & $66.45 \pm 0.43^{b}$ & $68.67 \pm 0.43^{\mathrm{b}}$ & $34.70 \pm 0.14^{\mathrm{b}}$ & $33.65 \pm 0.40^{\mathrm{b}}$ & $31.55 \pm 0.53^{\mathrm{c}}$ \\
\hline
\end{tabular}

Values are mean $\pm S D ; n=3$. The values in a column, within a set, followed by same superscript letters are not statistically different at the significance level of $5 \%$

The difference between sample D and F was modified flour (PG-II) concentration ( $1 \%$ and $0.5 \%$, respectively). Reduced flour concentration could be attributed to the decrease in post acidification which could also be identified by the $\mathrm{pH}$ value of samples during storage period. Sample D showed a $\mathrm{pH}$ reduction of 0.29 after eight days of storage when compared to the initial stage while sample F showed only a 0.16 drop in $\mathrm{pH}$. It could also be related to increased TSS, since there is a strong relationship between TSS and acidity with the growth rate of starter culture.

\section{Moisture and Total Solids Contents of Yoghurt}

The moisture content of yoghurt samples make it less viscous thereby, affecting texture and mouth feel. It mostly causes the problem of syneresis (whey separation) during storage. The main cause of this problem is due to shrinkage of gel. By using a suitable stabilizer this situation can be controlled.

The moisture contents of all yoghurt samples (<70\%; Table 3) corresponded with the report of Ahmad (1994) who stated that the maximum moisture content of yoghurt should be $84 \%$ to maintain the suitable texture. Among all formulations, sample D showed the best water holding quality during storage with a $12.07 \%$ decrease in moisture content from the initial value on $1^{\text {st }}$ day. The reason could be possibly the usage of different processes which provided more time to get hydrated and to combine starch particles with milk. 
Table 4. Sensory properties of drinking yoghurt formulated with Kithul flour

\begin{tabular}{|c|c|c|c|c|c|c|c|c|}
\hline 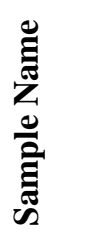 & $\frac{\grave{\Xi}}{\dot{\theta}}$ & $\grave{\Xi}$ & 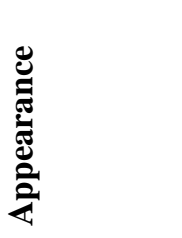 & 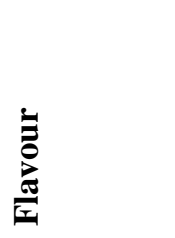 & 党 & : & 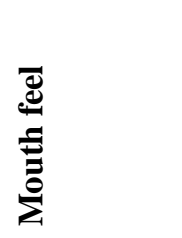 & 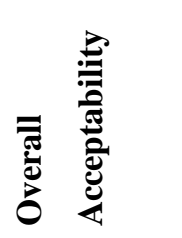 \\
\hline \multicolumn{9}{|c|}{$1^{\text {st }}$ Set } \\
\hline A & $4.76 \pm 2.05^{\mathrm{a}}$ & $5.47 \pm 0.97^{\mathrm{a}}$ & $5.13 \pm 1.52^{\mathrm{b}}$ & $5.30 \pm 1.47^{\mathrm{a}}$ & $5.27 \pm 1.28^{\mathrm{a}}$ & $5.60 \pm 1.07^{\mathrm{a}}$ & $5.17 \pm 1.49^{b}$ & $5.47 \pm 1.41^{\mathrm{a}}$ \\
\hline B & $4.37 \pm 1.65^{\mathrm{a}}$ & $5.80 \pm 1.06^{\mathrm{a}}$ & $5.47 \pm 1.22^{\mathrm{a}}$ & $5.50 \pm 1.31^{\mathrm{a}}$ & $5.30 \pm 1.34^{\mathrm{a}}$ & $5.80 \pm 1.00^{\mathrm{a}}$ & $6.07 \pm 1.17^{\mathrm{a}}$ & $5.73 \pm 1.41^{\mathrm{a}}$ \\
\hline $\mathrm{C}$ & $4.47 \pm 1.89^{\mathrm{a}}$ & $5.27 \pm 1.14^{\mathrm{a}}$ & $5.03 \pm 1.59^{\mathrm{c}}$ & $5.47 \pm 1.17^{\mathrm{a}}$ & $4.80 \pm 1.65^{\mathrm{a}}$ & $4.80 \pm 1.00^{\mathrm{b}}$ & $4.73 \pm 1.39^{b}$ & $4.60 \pm 1.52^{\mathrm{b}}$ \\
\hline \multicolumn{9}{|c|}{$2^{\text {nd }}$ Set } \\
\hline B & $4.37 \pm 1.65^{\mathrm{b}}$ & $5.80 \pm 1.06^{\mathrm{a}}$ & $5.47 \pm 1.22^{\mathrm{ab}}$ & $5.50 \pm 1.31^{\mathrm{a}}$ & $5.30 \pm 1.34^{\mathrm{a}}$ & $5.80 \pm 1.00^{\mathrm{ab}}$ & $6.07 \pm 1.17^{\mathrm{a}}$ & $5.73 \pm 1.41^{\mathrm{ab}}$ \\
\hline $\mathrm{D}$ & $4.37 \pm 1.65^{\mathrm{b}}$ & $5.70 \pm 1.12^{\mathrm{a}}$ & $5.97 \pm 1.10^{\mathrm{a}}$ & $6.00 \pm 1.26^{\mathrm{a}}$ & $5.30 \pm 1.34^{\mathrm{a}}$ & $5.97 \pm 1.03^{\mathrm{a}}$ & 6. $20 \pm 1.21^{\mathrm{a}}$ & $6.07 \pm 0.94^{\mathrm{a}}$ \\
\hline $\mathrm{E}$ & $5.87 \pm 1.17^{\mathrm{a}}$ & $5.70 \pm 1.12^{\mathrm{a}}$ & $4.77 \pm 1.38^{\mathrm{b}}$ & $5.87 \pm 1.36^{\mathrm{a}}$ & $5.10 \pm 1.30^{\mathrm{a}}$ & $5.20 \pm 1.13^{\mathrm{b}}$ & $5.03 \pm 1.73^{b}$ & $5.27 \pm 1.41^{\mathrm{b}}$ \\
\hline \multicolumn{9}{|c|}{$3^{\text {rd }}$ Set } \\
\hline $\mathrm{D}$ & $4.37 \pm 1.65^{\mathrm{b}}$ & $5.70 \pm 1.12^{\mathrm{a}}$ & $5.97 \pm 1.10^{\mathrm{a}}$ & $6.00 \pm 1.26^{\mathrm{a}}$ & $5.30 \pm 1.34^{\mathrm{a}}$ & $5.97 \pm 1.03^{\mathrm{a}}$ & $6.20 \pm 1.21^{\mathrm{a}}$ & $6.07 \pm 0.94^{\mathrm{a}}$ \\
\hline $\mathrm{E}$ & $5.87 \pm 1.17^{\mathrm{a}}$ & $5.70 \pm 1.12^{\mathrm{a}}$ & $4.77 \pm 1.38^{\mathrm{a}}$ & $5.87 \pm 1.36^{\mathrm{a}}$ & $5.10 \pm 1.30^{\mathrm{a}}$ & $5.20 \pm 1.13^{\mathrm{b}}$ & $5.03 \pm 1.73^{\mathrm{b}}$ & $5.27 \pm 1.41^{\mathrm{b}}$ \\
\hline $\mathrm{F}$ & $4.83 \pm 1.78^{b}$ & $5.70 \pm 1.12^{\mathrm{a}}$ & $5.17 \pm 1.53^{\mathrm{a}}$ & $5.87 \pm 1.36^{\mathrm{a}}$ & $5.30 \pm 1.34^{\mathrm{a}}$ & $5.80 \pm 1.00^{\mathrm{ab}}$ & $6.07 \pm 1.17^{\mathrm{a}}$ & $5.73 \pm 1.14^{\mathrm{ab}}$ \\
\hline
\end{tabular}

Values are mean $\pm S D ; n=3$. The values in a column, within a set, followed by same superscript letters are not statistically different at the significance level of 5\%; Scale: 7-Like extremely to 1-Dislike extremely

Total solids contents of all drinking yoghurt samples were affected significantly by the storage period (Table 3). Results of samples $\mathrm{A}, \mathrm{B}, \mathrm{C}$ and $\mathrm{F}$ were in agreement with that of Anjum et al. (2007) who reported that total solids gradually decreased during the storage period because of utilization of sugar by microbes. However, samples D and E did not align with above results.

By considering the above chemical parameters, it shows that the samples B and $\mathrm{D}$ are more capable of resisting the changes, retaining microbial activity under control and causing less whey separation. Modified flour (Process II) can bind water and therefore sample D is more suitable than sample $\mathrm{B}$, to retain the original qualities of drinking yoghurt.

\section{Sensory Characteristics of Drinking Yoghurt}

Sensory scores received for fresh samples of the three sets of drinking yoghurt are presented in Table 4 and Figure 2. Except for the control sample (E), colour of the new formulation was not significantly different ( $>0.05)$ while sample $\mathrm{E}$ had the highest rank as 5.87. Preferences for odour, flavour and acidity of all six samples were not 
significantly different. However, the highest score for odour was achieved by sample B (5.80). The best score for flavour among six samples was obtained by sample D (6.00). Samples B, D and F received a same score of 5.3 which was more acceptable compared to the control (E). Thermal degradation of some constituents of milk forms volatile compounds, including acetaldehyde which is one of the key aroma compounds (El Owni and Mahgoub, 2012).

Appearance of the drinking yoghurt is a key factor to determine consumer preference. The results indicated that appearance was significantly affected by the concentration, type of Kithul flour and the process applied. From the $1^{\text {st }}$ set of samples, sample B had the highest score (5.47) while sample D (5.97) was ranked as the best appearance from $2^{\text {nd }}$ and $3^{\text {rd }}$ sets (Table 4 ).

Among sensory attributes, the second most important character of the product to attract consumers is the texture which is influenced by factors such as the total viable count and acidity that affect the action of stabilizers (Crion et al., 2012). From the $1^{\text {st }}$ set of drinking yoghurt samples, sample B which scored as the best (5.8) was significantly different $(\mathrm{p}<0.05)$ from others. From $2^{\text {nd }}$ and $3^{\text {rd }}$ sets, sample D was ranked (5.97) as the best in texture quality with a significant difference. Among all yoghurt samples, the highest scores were received by D followed by A, B, C, E and F.
Mouthfeel describes the combination concept of acidity flavour and texture. It was corresponding to the results of texture evaluation. When the sample B was ranked with the highest score (6.07) from the $1^{\text {st }}$ set, sample D received a score of 6.20 as the best sample among other two sets as well as among all six samples on the sensory quality of mouth feel (Table 4).

When considering sensory attributes, overall acceptability is the most important parameter to select the best sample among new formulations of drinking yoghurt developed with modified Kithul flour. The results depicted in Table 4 and Figure 2 showed that overall acceptability of samples was significantly affected by the concentration, type of Kithul flour and the applied process for sample preparation. Samples B, D and F achieved the highest scores of 5.73, 6.07 and 5.73, respectively.

Those three formulations contained the same type of flour (i.e. PG-II Kithul flour) as a stabilizer. The difference between B and D is the process while the difference between $\mathrm{D}$ and $\mathrm{F}$ is the concentration of Kithul flour. Based on both physico-chemical and sensory parameters, sample D which was prepared with $1 \%$ of modified Kithul flour (PG-II) in process II resulted in the best drinking yoghurt formulation. 


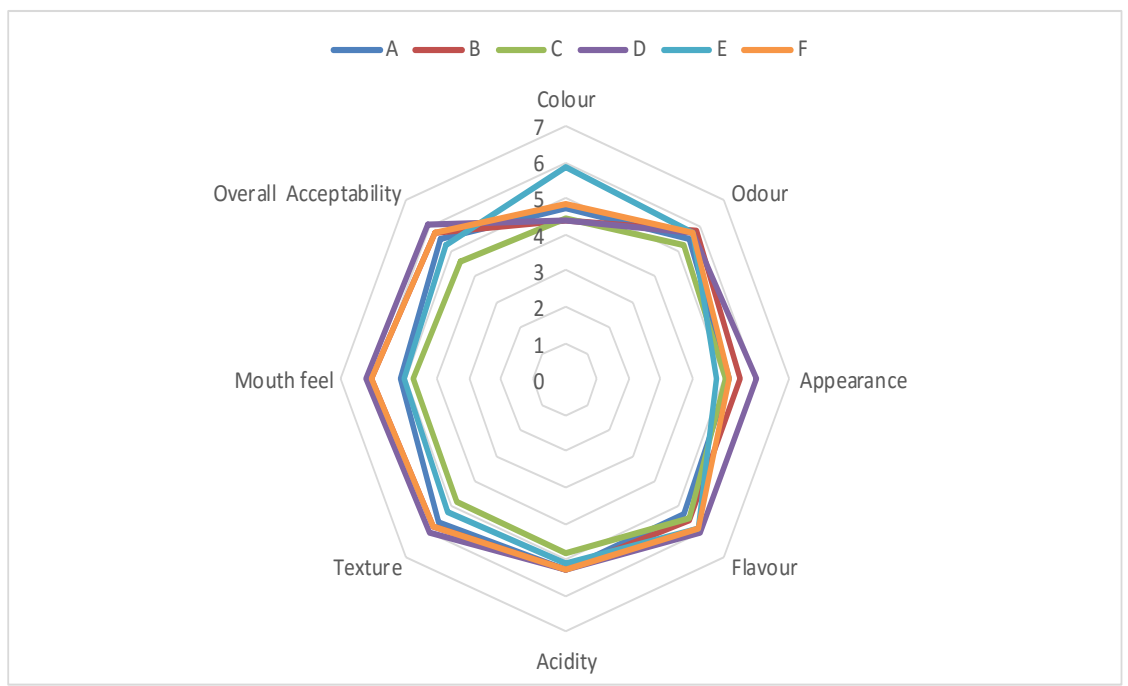

Figure 2. Comparison of sensory properties of formulated drinking yoghurt Scale: 7-Like extremely to 1-Dislike extremely

\section{CONCLUSION}

Pre-gelatinized modified Kithul (Caryota urens) flour namely PG-II (pre-gelatinized at $75{ }^{\circ} \mathrm{C}$ for $5 \mathrm{~min}$ ) is the best type of Kithul flour among others. The best process to maintain most preferable conditions for drinking yoghurt is process II, which provides $24 \mathrm{~h}$ of refrigeration to combine starch granules with milk. Based on results of the $8^{\text {th }}$ day of storage period $\left(3^{\text {rd }}\right.$ set) from among samples D, E and F, the best Kithul flour concentration to keep the unique texture and consumer preference of newly formulated drinking yoghurt is $1 \%$.

\section{ACKNOWLEDGEMENT}

Authors thank the University of Sri Jayewardenepura, Sri Lanka for providing financial assistance (Grant No: ASP/06/RE/SCI/2012/04) for this study.

\section{REFERENCES}

Aguirre-Mandujano, E., Lobato-Calleros, C., Beristain, C. I., Garcia, H.S. and Vernon-Carter, E.J. (2009). Microstructure and viscoelastic properties of low-fat yoghurt structured by monoglyceride gels. Food Science and Technology, 42: 938-944.

Ahmad, J. (1994). Quality characteristics of plain yoghurt made from standardized Buffallo milk. M.Sc Thesis University of Agriculture, Faisalabad, Pakistan.

Anjum, R. R., Zahoor, T. and Akhtar, S. (2007). Comparative study of yoghurt prepared by using local isolated and commercial imported starter culture. 
Journal of Research (Science), 18(1): $35-41$.

Anon. (1992). The Wealth of India. A Dictionary of Indian Raw Materials and Industrial Products. In: Raw Materials. Ca-Ci. Publications and Information Directorate. Council of Scientific and Industrial Research, New Delhi. 876.

AOAC (2005). Official Methods of Analysis. $12^{\text {th }}$ edition. Association of Official and Analytical Chemists, Washington DC.

Bibiana, I., Joseph S. and Julius, A. (2014). Physicochemical, microbiological and sensory evaluation of yoghurt sold in Makurdi metropolis. African Journal of Food Science and Technology, 5(6): 129-135

Crion, C.I. E., Gee, V. L., Kelly, A. L. and Auty, M.A.E. (2012). Modifying the microstructure of low-fat yoghurt by micro-fluidization of milk at different pressures to enhance rheological and sensory properties. Food Chemistry, 130: 510-519.

Collins, J.L., Ebah, C.B., Mount, J.R., Demott, B.J. and Draughon, F.A. (1991). Production and evaluation of milk-sweet potato mixtures fermented with yoghurt bacteria. Journal of Food Science, 56(3): 685-688.

Donkor, N., Henrikson, A., Vasiljevic, T. and Shah, N.P. (2006). Effect of acidification on the activity of probiotics in yoghurt during cold storage. International Dairy Journal, 16(10): 1181-1189.

El Owni, O.A.O. and Mahgoub, M.S.A.
(2012). The effect of storage on chemical, microbial and sensory characteristics of goat's milk yoghurt. Journal of Novel Applied Sciences, 1(2): 63-67.

Foss, J.W. (2000). How Processing Affects Starch Selection for Yoghurt. National Starch and Chemical Company, Bridgewater, New Jersey.

Karaoglu, M.M., Kotancilar, H.G. and Celik, I. (2001). Effects of utilization of modified starches on the cake quality. Starch, 53: $162-169$.

Karim, A.A. and Bhat, R. (2009). Fish gelatin: properties, challenges, and prospects as an alternative to mammalian gelatins. Food Hydrocolloids, 23: 563-576.

Knight, J.W. (1969). The Starch Industry. Pergman Press Ltd., Oxford.

Kumar, P. and Mishra, H. (2004). Mango soy fortified set yoghurt: effect of stabilizer addition on physicochemical, sensory and textural properties. Food Chemistry, 87(4): 01-507.

Lal, S.N.D., O'Connor, C.J. and Eyres, L. (2006). Application of emulsifiers/stabilizers in dairy products of high rheology. Advances in Colloid and Interface Science, 123-126: 433437.

Lee, W.J. and Lucey, J.A. (2010). Formation and physical properties of yogurt. Asian-Australasian Journal of Animal Sciences, 23(9): 112 -1136.

Okoth, E.M., Kinyanjui, P.K., Kinyuru, J. N. and Juma, F.O. (2011). Effects of 
substituting skimmed milk powder with modified starch in yoghurt production. Journal of Agriculture, Science and Technology, 13(2): 13-30.

Rajyalakshmi, P. (2004). Caryota palm sago - A potential underutilized natural resource for modern starch industry. Natural Product Redience, 3(3): 144149.

Shahnawaz, M., Sheikh, S. A. and Akbar, Z. A.I (2013). Physicochemical analysis of desi yoghurts produced by the local community in Gilgit District. African Journal of Food Science, 7(7): 183-185.

Tamime, A.Y. and Rabinson, R.K. (1999).

Yoghurt Science and Technology, Woodhead Publishing Limited, Boston.

Tavakolipour, H., Vahid-moghadam, F. and Jamdar, F. (2014). Textural and sensory properties of low fat concentrated flavored yogurt by using modified waxy corn starch and gelatin as a fat replacer. International Journal of Biosciences, 5(6): 61-67.

Vasconcelos, C.M., Minim, V.P.R. and Chaves, J.B.P. (2012). Low-calorie yogurt added with yacon flour: development and physicochemical evaluation. Revista Chilena de Nutricion, 39 (3): 65-71.

Vasiljevic, T. and Jelen, P. (2002). Lactose hydrolysis in milk as affected by neutralizers used for the preparation of crude $\beta$-galactosidase extracts from Lactobacillus bulgaricus 11842. Innovative Food Science and Emerging Technologies, 3: 175-184.
Wang, Y. C., Yu, R. C. and Chou, C. C. (2002). Growth and survival of bifidobacteria and lactic acid bacteria during the fermentation and storage of cultured soymilk drinks. Food Microbiology, 19: 501-508.

Wijesinghe, J. A. A. C., Wicramasinghe, I. and Sarananda, K.H. (2014). Kithul flour (Caryota urens) as new plant origin gelatinizing agent with a product development of fruit-based dessert. Engineering International, 2(2): 72-78. 